\title{
Incorporation of Soy Protein Based Biopolymer as Binder on Woven and Nonwoven Natural Fabric
}

\author{
Rakesh Kumar* \\ Department of Biotechnology Program, Centre for Biological Sciences, Central University of South Bihar, India
}

Submission: September 22, 2017; Published: January 05, 2017

*Corresponding author: Rakesh Kumar, Department of Biotechnology Program, Centre for Biological Sciences, Central University of South Bihar, Patna - 800014, India, Tel: +91-9709474061; Email: krrakesh72@gmail.com, rakeshkr@cusb.ac.in

\section{Opinion}

Natural fibers are hydrophilic and biodegradable in nature. These fibers can be prepared into woven and non-woven web. The nonwoven fabrics prepared by randomly assembling individual fibers in form a web are subsequently bonded by chemical, thermal or mechanical means. Among all the three methods mentioned above to bind fibres, an environment friendly method that is foam application and impregnation technique of aqueous binder system i.e., acrylic binder has gained acceptance because of less energy requirements. This method is more prevalent method in the industry for adhesive bonding of nonwoven fabrics for certain applications. Also for woven fabric, one uses synthetic polymers i.e., phenolics and epoxies impregnation either by solution casting or compression molding methods.

In nature, there are binders available from renewable resources in form of carbohydrates and proteins. Bio-based binder from carbohydrate, such as dextrin or mal to dextrin, and cross-linking agent, such as citric acid, in presence and absence of the other additives has been patented $[1,2]$. Inexpensive plant based soy protein binders have also been reported [3]. Soy Protein Isolate (SPI) is a biopolymer obtained from plant resources and can be used as an adhesives and binders in addition to its film forming ability. Neat SPI and sodium dodecyl sulphate modified SPI based water-soluble binder composition have been prepared by Kumar et al. for binding viscose fiber by foam application method resulting in nonwoven viscose fabric [4]. In this work, author has tried to use SPI based binder to bind viscose fiber by foam application methods as well as by impregnation technique. Authors have also used commercial acrylic binder in addition to SPI based bio binder for preparing protein and acrylic-bonded viscose fabrics. These fabrics were subjected to mechanical, thermal and water absorption studies. Soy protein-based biobinder can be exploited to develop a variety of products, from dry and wet wipes to disposable sanitary fabrics, such as diapers, sanitary napkins, bandages etc. Both impregnation and foam application methods were successfully employed to prepare the viscose fabrics from soy protein-based binder formulations. The advantages of using soy protein based bio-binder compositions are that it is free from formaldehyde as well as derived from plant sources and hence are eco-friendly.

SPI resin as well as arylated SPI resin can also be used to prepare an impregnated woven fabric $[5,6]$. In the first stage, a resin was prepared by mixing SPI with $30 \%$ plasticizer with a $\mathrm{pH}$ of about 9.5-10.00. Non-woven flax fabrics are wetted in the SPI resin and then dried in an oven to get the SPI coated nonwoven fabric. The SPI impregnated woven fabrics are then immersed in benzilic acid to obtain arylated SPI coated nonwoven fabric with high mechanical properties and low water uptake. The arylated samples showed brittle-matrix behavior with stick-slip mechanism this was well confirmed by the presence of cracks on the surface of the arylated composites, as evidenced from scanning electron microscopy SEM. In the category of woven fabric, if one wants to prepare normal SPI incorporated woven fabric then neat SPI can be used, however for hydrophobic SPI incorporated woven fabric arylated SPI can be used. PLA fabrics which fall in the category of biopolymeric fabric can also be binded with SPI and arylated SPI with nomex based honeycomb core. Assessed interfacial interactions between arylated SPI and PLA by fracture morphology [7]. Hence, it is evident that plant based SPI binder, being aqueous in nature, can be successfully used to bind particularly woven and non-woven fabric.

\section{References}

1. Hawkins CM, Hernandez-Torres JM, Chen L (2011) Bio-based binders for insulation and non-woven mats. Patent 20110086567A1, USA.

2. Herwinjen HWGV, Pisanova E and Sterfke B (2011) Renewable binder for nonwoven materials. Patent 7,893,154 B2, USA.

3. Thames SF, Sankovich BG, Shera JN (2006) Soy protein based adhesive and particle board. Patent 7,081,159, USA.

4. Kumar R, Zhang L (2008) Water induced hydrophobicity of soy protein materials containing 2,2-diphenyl-2-hydroxyethanoic acid. Biomacromolecules 9(9): 2430-2437.

5. Kumar R, Moyo D, Anandjiwala RD (2015) Viscose fabric bonded with soy protein isolate by foam application method. Journal of Industrial Textiles 44(6): 849-867. 
6. Kumar R, Anandjiwala RD (2012) Flax fabric reinforced arylatedsoy protein composites: A brittle-matrix behaviour. Journal of Applied Polymer Science 124(4): 3132-3141.
7. Kumar R, Moyo D (2012) Fabrication and properties of pla fabric based sandwich panels with arylated soy protein isolate as the binder.Journal of Biobased Materials and Bioenergy 6(5): 521-530.

\section{Your next submission with Juniper Publishers} will reach you the below assets

- Quality Editorial service

- Swift Peer Review

- Reprints availability

- E-prints Service

- Manuscript Podcast for convenient understanding

- Global attainment for your research

- Manuscript accessibility in different formats

( Pdf, E-pub, Full Text, Audio)

- Unceasing customer service

Track the below URL for one-step submission https://juniperpublishers.com/online-submission.php 